University of Nebraska - Lincoln

DigitalCommons@University of Nebraska - Lincoln

Egyptian textiles and their production: 'word' and 'object'

Centre for Textile Research

$3-2-2020$

\title{
Dyeing in texts and textiles: words expressing ancient technology
}

\author{
Ines Bogensperger \\ University of Vienna \\ Helgo Rösel-Mautendorfer \\ University of Vienna
}

Follow this and additional works at: https://digitalcommons.unl.edu/egyptextiles

Part of the Africana Studies Commons, African Languages and Societies Commons, Classical Archaeology and Art History Commons, Fiber, Textile, and Weaving Arts Commons, History of Art, Architecture, and Archaeology Commons, and the History of Science, Technology, and Medicine Commons

Bogensperger, Ines and Rösel-Mautendorfer, Helgo, "Dyeing in texts and textiles: words expressing ancient technology" (2020). Egyptian textiles and their production: 'word' and 'object'. 9.

https://digitalcommons.unl.edu/egyptextiles/9

This Article is brought to you for free and open access by the Centre for Textile Research at DigitalCommons@University of Nebraska - Lincoln. It has been accepted for inclusion in Egyptian textiles and their production: 'word' and 'object' by an authorized administrator of DigitalCommons@University of Nebraska - Lincoln. 


\title{
Dyeing in texts and textiles: words expressing ancient technology
}

\author{
Ines Bogensperger \& Helga Rösel-Mautendorfer
}

\section{Introduction}

The complex chaîne opératoire of ancient textile production in various stages has been frequently discussed by textile scholars. ${ }^{1}$ According to documentary papyri, textile manufacturing represented the highest taxed industry after agriculture. This emphasises its importance as a significant sector in the ancient economy. A highly specialised branch within the chaîne opératoire is the dyeing industry. Ancient dyers used natural and animal dyestuffs, as well as different dyeing techniques to achieve their colourful results. ${ }^{2}$ They were also aware of the specific properties of the different textile fibres. In ancient times, wool and linen were the characteristic materials for manufacturing textiles, but archaeological and papyrological sources further attest the use of cotton, silk and even goat hair. ${ }^{3}$ Depending on the particular fibre properties and the natural pigmentation, different results, colours and hues could be achieved. Preserved textiles show that mainly wool was dyed, but there are dyed linen textiles as well. ${ }^{4}$
The present paper aims to examine the outstanding mastery, skills and practical knowledge that are seen in both Greek documentary papyri and preserved late antique textiles. ${ }^{5}$ We also would like to point out an indicative modus operandi to determine ancient technology.

\section{Textual evidence ${ }^{6}$}

\section{Greek documentary papyri}

The vast corpus of Greek documentary papyri offers us valuable insight into the ancient dyeing industry and specific economic activities that are impossible to assess from the preserved objects. In the texts, garments and other fabrics are usually described by their colours. Several studies have examined words for colours and their meaning in literary and documentary sources. ${ }^{7}$ The Greek terms either evoke a particular dyestuff or use a comparative image to describe the colour. In particular, the purple obtained from mollusc species has often been examined by scholars. Being a rare

Published in Maria Mossakowska-Gaubert, ed., Egyptian Textiles and Their Production: 'Word' and 'Object' (Hellenistic, Roman and Byzantine Periods) (Lincoln, NE: Zea Books, 2020). doi 10.32873/unl.dc.zea.1086

1. For example, Andersson Strand 2012.

2. Schweppe 1993; Hofenk de Graaff \& Roelofs 2004; Cardon 2007.

3. For example, Wild 1970, p. 4-21; Bagnall 2008; Rast-Eicher 2016, p. 74, 88, 252, 262 and 282-283.

4. In literature, one can occasionally read that linen was difficult to dye, a statement which is per se not correct. The treatment and the obtained results differ from wool, silk or cotton. On the topic of dyeing linen in Pharaonic Egypt, see Goyon 1996.

5. This paper is a result of the research project “Texts and Textiles from Late Antique Egypt", funded by the Austrian Science Fund, FWF-P 28282. We are thankful to all our friends and colleagues for their support, especially, Regina Hofmann-de Keijzer, Mathijs de Keijzer, Maarten R. van Bommel, Helmut Eberhart, Ineke Joosten, Georg Rösel, Mark Clarke, Bernhard Palme, Peter Bichler, Ingrid Balka, and Joseph Koo. We are grateful to Hildegard Kirchweger, who corrected our English.

6. For lexicographical studies of Greek terminology for the action of textile dyeing, see the article by Peder Flemestad, in this volume (Flemestad 2020).

7. For example, Reiter 1962; Warp 1997; Andorlini 1998; Froschauer 2007. 


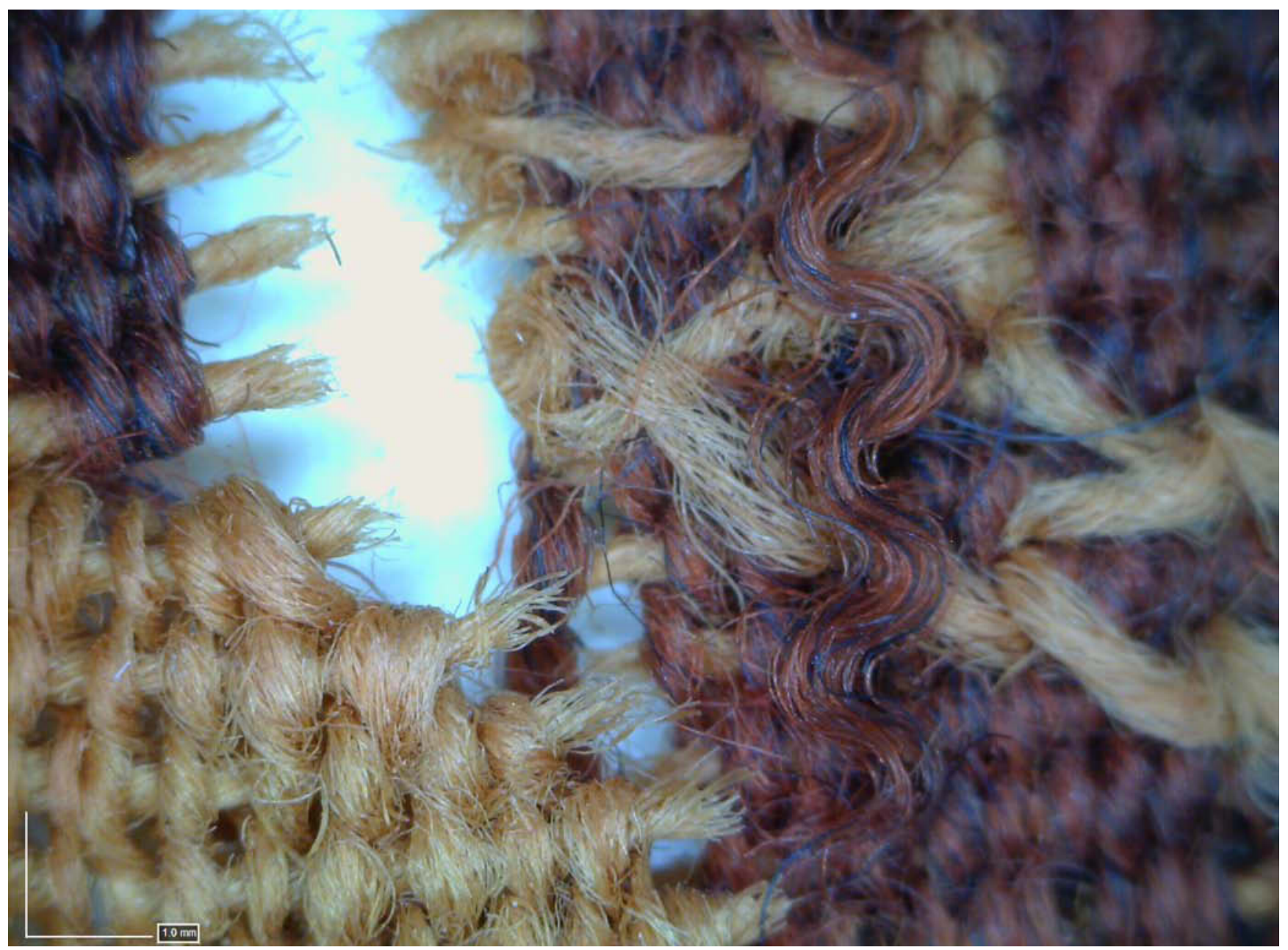

Figure 1. Yarns consisting of blue and red dyed fibres used for a tapestry: $P$. Vindob. Stoff 270, Papyrussammlung, Austrian National Library. (Photo: Maarten R. van Bommel (c) Austrian National Library, Vienna).

and precious colour, it has a certain attraction, which can be also observed for insect dyes. The majority of analysed textiles, however, show the use of plant dyestuffs, often a combination of blue and red. ${ }^{8}$ This was used not only in overdyeing, but also in spinning blue- and red-dyed fibres to obtain purple (fig. 1). Only a few papyrus documents suggest the use of mollusc dyestuff. ${ }^{9}$ This corresponds well to the general picture we get from the dyestuff analyses, that is to say, mollusc purple was still used in late antiquity but only for a few textiles.

Amongst the numerous colour terms, $\beta \lambda \alpha$ á $\tau \alpha$ is a prominent example. Initially, it denotes mollusc purple and in this sense it is found in the legal sources Codex Theodosius
(Cod. Theod. 10.20.13; 10.20.18) and Codex Iustinianus (Cod. Iust. 10.21.3; N 40.1). However, some words change their meaning over time. Rodolphe Guilland states that in the $10^{\text {th }}$ century Book of Ceremonies, blattion denotes rather silken textiles regardless of their colour..$^{10}$

Papyrus texts demonstrate that not only were various dyeing materials distinguished but also different grades of a particular dyestuff. In the declaration of prices by a guild, P. Oxy. LIV 3765 (c. AD 327), we encounter two categories of quality for the same dyestuff: коккívov $\alpha \lambda i(\tau \rho \alpha \varsigma)$ $\alpha \tau \alpha^{\prime} \lambda(\alpha v \tau \alpha) \eta \mid \beta$ коккívov $\lambda i ́(\tau \rho \alpha \varsigma) \alpha \tau \alpha^{\prime} \lambda(\alpha \nu \tau \alpha) \beta$ (ll. 19-20). The text records one pound of kermes of first grade quality $(\alpha)$ for eight talents, while one pound of kermes of second

8. Already noted by the French chemist, Rodolphe Pfister (Pfister 1937, p. 12).

9. See Worp 1997; Bogensperger 2017.

10. Guilland 1949, p. 333-348; recently Morelli 2017, p. 133 n. 14. 
grade $(\beta)$ is priced at two talents. ${ }^{11}$ Harald Froschauer suggests that the difference results from different insect species. ${ }^{12}$ It might further be possible that the processing of the insects had a significant impact on the quality and hence the price of the commodity. A comparable situation can be observed for the American cochineal from Mexico. ${ }^{13}$ At any rate, it is plausible that dyestuffs were priced also by quality, which illustrates not only the production and supply chain of dyestuffs but also the professional knowledge of ancient dyers, who had to select their materials carefully.

Documentary papyrus texts give us some clues as to the economic environment. We encounter the occupation

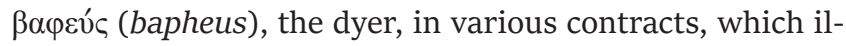
lustrates their active role in ancient business life. Baphoi are widely attested in papyrological and epigraphical doc-

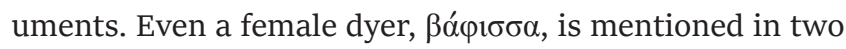
papyri: P. Oxy. XXIV 2421, 47 (AD 312-323) ${ }^{14}$ and O. Petr. Mus. $449,1-2=S B$ I 1957, 1-2 ( $4^{\text {th }}$ century AD). Kai Ruffing notes in his comprehensive study that the collegia of dyers are known from Imperial Roman inscriptions. ${ }^{15}$

Renate Germer investigated texts from Pharaonic times and she identifies pś jnś (literally "boiler of linen”) as "dyer" in five texts from the New Kingdom and in one from the time of Hadrian. ${ }^{16}$ This meaning, however, seems to be questionable, especially as we find the professional occu-

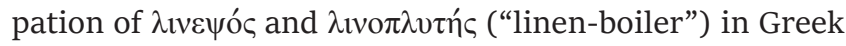
documentary papyri. The activity is more probably connected with the processing of linen, including bleaching. ${ }^{17}$ According to Ewa Wipszycka, linoplytes replaced the Ptolemaic linepsos in the Roman era. ${ }^{18}$

Apart from the craftsman, we learn of dyeing workshops, bapheia, for which leasing contracts were agreed: P. Osl. III 139 is possibly an example from the $2^{\text {nd }}$ century $\mathrm{AD}$, however, the text is too fragmentary to provide further information. The $6^{\text {th }}$ century contract $C P R$ XIV 10, 13 explicitly names its purpose as $\mu$ í] $\sigma \theta(\omega \sigma \iota \varsigma) \stackrel{\varepsilon}{\rho} \gamma \alpha \sigma \tau \eta \rho$ (íov) $\beta \alpha \varphi(\varepsilon v \tau \iota \kappa o v)$ on its verso. The dye workshop was leased by brothers presumably from Flavius Apion II, a large estate owner. ${ }^{19} P$. Ross.Georg. III 38, also dated to the $6^{\text {th }}$ century, shows that a former general store is leased as a dyer's workshop. The place is located in a private house, next to the southern agora of Antinoopolis, a public market place of the city. ${ }^{20}$

The dyeing industry and all its craftsmen depended on a complex supply chain providing them with various materials and ingredients. In particular, additives, i.e. additional substances needed for dyeing, were traded over distances.

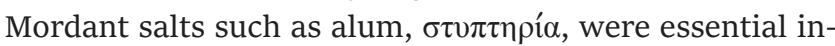
gredients. Alum was the main mordant, as we see in dyeing recipes, which was mined in the oases of Egypt's Western Desert. Its mining, transport and trade were carefully regulated in a state-controlled monopoly. ${ }^{21}$

In addition, papyrus texts reveal particular means of communication to express a desired hue, which is better known from later times. Clients and dyers used colour patterns, small samples of dyed wool, to specify the hue. Samples also served as references for the purchase of wool of a particular colour: in Roman literature we find the Latin term exemplum (cf. Rhet. Her. 4.5.9). In brief, the available evidence illustrates that ancient dyers did not produce their results randomly, but according to the customer's specific idea and concept. Samples and patterns, such as weaving cartoons, served as reproducible models.

To date, several known papyrus texts mention samples for ordering textiles, e.g.: BGU IV 1141, 40-43; P. Oxy. LV 3806, 7-13; P. Oxy. VIII 1153, 18-25; P. Giss.Apoll. 11, 14-16 $(=P$. Giss. I 20, 14-16 = W. Chr. 94, 14-16); P. Oxy. I 113, 4-9. ${ }^{22}$ The term $\delta \varepsilon \hat{\gamma} \gamma \mu \alpha$ is often used, sometimes as a compound, and it is found as a loan word in the Coptic business letter $P$. Kellis VII 58, 15-20. ${ }^{23}$ Moreover, we find paraphrases or collocations that refer to a small amount of dyed wool.

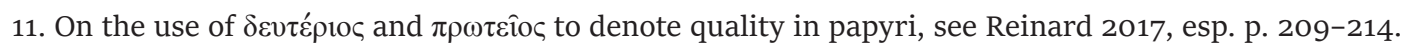

12. Froschauer 2007, p. 707.

13. Cardon 2007, p. 623; Roquero 2006, p. 143.

14. On the date, cf. BL VIII, p. 257.

15. A compilation of the papyrological evidence is provided by Ruffing 20o8, p. 453-459.

16. Germer 1992, p. 134-135.

17. Ruffing 2008, p. 640-641.

18. Wipszycka 1965, p. 23.

19. Kovarik 2012, p. 111-112; regarding the discussion on the location, cf. BL X, p. 54.

20. Andorlini 1998, p. 158.

21. Kruse 2007; Bogensperger 2017.

22. On ordering textiles, see Bogensperger 2016, see also the article by Aikaterini Koroli, in this volume (Koroli 2020); on the general topic of patterns and samples in Greek papyrus texts, see Bogensperger \& Koroli in prep.

23. We are grateful to Jennifer Cromwell for discussions regarding this term. 
The private letter P. Oxy. LV 3806, 7-13 (21 May, AD 15) perfectly illustrates the customer's expectations:

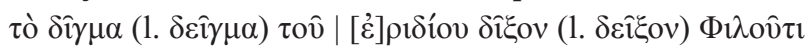

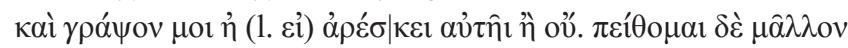

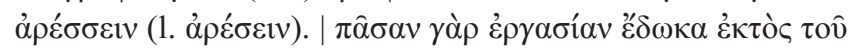

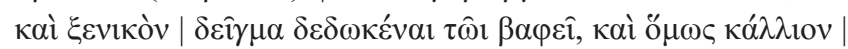

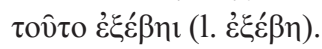

"Show the sample of wool to Philūs, and write me if it pleases her or not. I believe that it will rather please her, for I gave (it) every attention, besides having given the dyer an imported sample as well and even so this one turned out nicer". ${ }^{24}$

The evidence of colour samples has a significant impact on our understanding of how materials were chosen and ordered, and what expectations ancient dyers had to fulfil. To dye according to a specific colour sample with natural dyestuffs demonstrates the extraordinarily high skill level and expertise of ancient dyers, as we will demonstrate below in our dyeing experiments.

\section{Ancient dyeing recipes}

In addition to the evidence from documentary papyri, we find technical instructions, recipes, providing us not only with information that certain dyestuffs and materials were used, but also how and in what form. ${ }^{25}$ Following Conrad Leemans' publication of Papyrus Leidensis (P. Leid.), of which Papyrus no. $\mathrm{X}$ is particularly interesting for our study, Otto Lagercrantz named a closely related source as Papyrus Graecus Holmiensis (P. Holm.). ${ }^{26}$ Both papyri are categorised as so-called subliterary, or sometimes as paraliterary texts, a group that refers not to literary texts per se and also differs from documentary texts. P. Leid. and presumably also P. Holm. are said to have been found in Thebes. ${ }^{27}$ They are dated to the $3^{\text {rd }}-4^{\text {th }}$ century AD. ${ }^{28}$ Otto Lagercrantz emphasised the close connection between the two papyri, which he even calls "twins". ${ }^{29}$

Both were codices, however, they are preserved as separate papyrus sheets today. According to the first editor $\mathrm{O}$. Lagercrantz, P. Holm. is almost entirely preserved with the exception of some missing pages from the cover. ${ }^{30}$ The text of both P. Holm. and P. Leid. X was written in uncials script.

In both codices, recipes are compiled on various topics dealing with metallurgy, how to make alloys, producing gemstones, colouring various materials, and dyeing textiles. Several recipes have titles, but there is no general heading to the codex.

The recipes reflect what might best be summarised as ancient alchemical knowledge. Marcelin Berthelot argues that it is a "science qui avait pour but la fabrication et la falsification des matières d'or et d'argent". ${ }^{31}$ This statement sparked debates and theories that these were the texts of forgers. The chemist Karl Reinking finally refuted this suspicion, ${ }^{32}$ and the ancient recipes were gradually considered to be for practical dyeing experiments. ${ }^{33}$

Examining P. Holm. and P. Leid. X, one wonders to whom they were addressed. Without being able to provide a definitive answer, we have gathered some preliminary arguments regarding the readership.

M. Berthelot, mentioned above, observes the work of a craftsman but he evokes the image of "charlatanisme". ${ }^{34}$ He writes of an "artisan faussaire", who is interested in chemistry and magic. 35 The chemist K. Reinking argues that these recipes address the craftsman, the dyer. O. Lagercrantz cannot deny a certain degree of expertise and even the work of several generations in the knowhow of these recipes. He points out that the knowledge contained is not an invention, but a compilation of older sources. ${ }^{36}$

24. English translation, ed. pr., p. 176.

25. For a general overview on historic recipes, see Clarke 2013; Kirby et al. 2014, p. 35-48; Martelli 2014.

26. The papyrus with ancient recipes is labeled as 'X', therefore P. Leid. X; see Leemans 1885, p. 199-259.

27. Leemanns 1885, p. 199: "Papyrus Thebis inventus ...”; Lagercrantz 1913, p. 45-47.

28. Leemans 1885, p. 199: “... saeculo III ${ }^{\circ}$ exeunte aut $I V^{o}$ ineunte...”; late $3^{\text {rd }}$ century: Berthelot 1887, p. 22; Lagercrantz 1913, p. 53-54: not older than $4^{\text {th }}$ century; Halleux 1981, p. 22-24: time of Constantine; Kreuzner 2013, p. 124: late $3^{\text {rd }}-$ early $4^{\text {th }}$ century.

29. Lagercrantz 1913, p. 47-50.

30. Ibid., p. 51.

31. Berthelot 1887, p. 19-20.

32. Reinking 1938, p. IV.

33. See, for example, Martínez Garcia 2016.

34. Berthelot 1887, p. 22.

35. Ibid., p. 5.

36. Lagercrantz 1913, p. 69-70. 
To date, scholars agree that $P$. Holm. and P. Leid. are copies of a lost oeuvre of ancient alchemy. Both papyri are not the originals but were used as manuscripts by private "non-professional" persons. The uncials point to a broader audience. ${ }^{37}$ Following O. Lagercrantz, we conclude for the time being that the form of a codex, the palaeography and the content show at least some kind of publication addressing a readership with specialist knowledge in the field.

\section{Dyeing technology in the ancient recipes}

Inspired by the specialised knowledge attested in both documentary papyri and ancient dyeing recipes, we aim to seek a new approach through experimental archaeology. In modern dyeing recipes, a single main dyestuff is used, whereas in the ancient dyeing recipes, P. Holm. and P. Leid. X, various additives, an additional dyestuff or inorganic substances are combined, such as sodium carbonate (vítpov: e.g., P. Holm. 94, 632; P. Holm. 108, 753),38

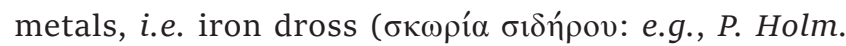
98, 661, P. Leid. X 99, 576), organic substances, such as blood (aij $\alpha$ : e.g., P. Holm. 156, 1098-1099: "pig's blood"), vinegar (o' P. Leid. X 94, 524), and pulses ( $\lambda \varepsilon \kappa i ́$ itov "bean-meal": e.g.,

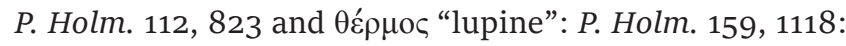
P. Holm. 118, 877).

The ancient recipes explicitly mention the use of different qualities of water, such as salt water $(\theta \alpha \dot{\lambda} \alpha \sigma \sigma \sigma \alpha$ : e.g., P. Holm. 102, 700), drinking water (

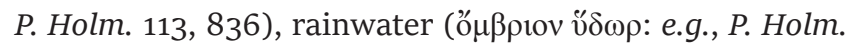

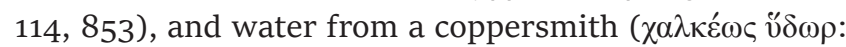
P. Holm. 118, 881). There are several indications of the duration (e.g., P. Holm. 96, 645 "overnight"; P. Holm. 105, 719 "for three days") and the temperature of the dye, such as boiling and cooling down (e.g., P. Holm. 101, 695), hot dyeing (e.g., P. Holm. 112, 820), and cold dyeing (e.g., P. Holm. 106, 727; P. Holm. 121, 899; P. Holm. 123, 912). Some recipes recommend an alkaline dye bath by adding ash ( $\sigma \pi \circ \delta$ óc: e.g., P. Holm. 112, 816).

Climatic conditions have an influence on the growth of plants and insects that might be decisive for the dye components. Climatic conditions also influence the drying process of the plants, or how long it takes to prepare the

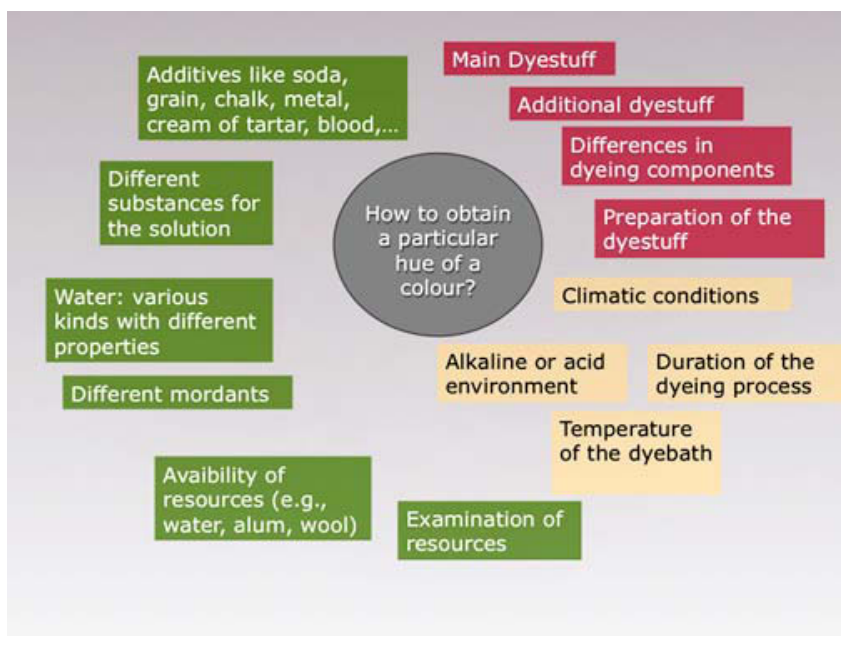

Figure 2. Various factors that influence the dyeing process and the colour. (Design and drawing (C) Helga Rösel-Mautendorfer \& Ines Bogensperger).

fermentation vat. All these parameters affect the hue (fig. 2). Moreover, the combination of various additives with different parameters clearly reflects how ancient knowledge and technology can modify the result, i.e. the final colour. At any rate, we get the impression that the dyeing process was more sophisticated than generally assumed and that variations and modifications need to be considered. Thus, thorough planning of the dyeing process was required.

\section{Dyeing experiments}

Dyeing experiments are frequently included in textile research. They are performed in laboratories with controlled conditions. ${ }^{39}$ Naturally, the material used is "of modern date", in other words, it is almost impossible to get old breeds of sheep and dye plants. Usually, small amounts are dyed in a sterile condition, which differs from the conditions of ancient daily life where large quantities of fibres, yarns, or textiles were necessary for manufacturing textiles. We get some hints from the archaeological evidence of dyeing workshops, for example in Pompeii, ${ }^{40}$ as well as from papyrus texts, where the employment contract $C P R$ XIX 33 attests the dyeing of fabric (fig. 3): $:^{41}$

37. Ibid., p. 88.

38. On nitron cf. further Beekes 2010, p. 1022 s.v.

39. For example, CHARISMA Project “Natural Colorants for Dyeing and Lake Pigments" (2009-2014); see Kirby et al. 2014; FWF research project (L431-Go2) "Dyeing techniques of the prehistoric Hallstatt-Textiles: analysis, experiments and inspiration for contemporary application" (2008-2012), see Hartl et al. 2015a, b.

40. Flohr 2013, p. 6o-62. Lowe 2016, p. 239-244.

41. On the date AD 591, Oct. 19-27, cf. BL XIII, p. 80. 


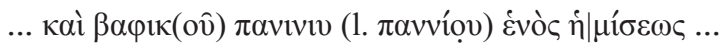

"... and $1 \frac{1}{2} 2$ pieces of cloth (pannus) suitable for dyeing ..."

Experiments in the laboratory are quite useful to understand the dyeing process and to test the different parameters of a recipe. In order to examine how ancient dyers really worked in the past, we performed several experiments in a non-sterile environment using ceramic vessels, an open fireplace, or pits filled with water and heated with hot stones.

\section{The textile fragment $P$. Vindob. Stoff 256}

The fragment inventoried as $P$. Vindob. Stoff 256 originates from a burial ground of late antique Egypt and is housed in the Papyrussammlung of the Austrian National Library, Vienna. ${ }^{42}$ It is $64.1 \mathrm{~cm}$ long and $148.4 \mathrm{~cm}$ wide. Wool was used in various colours and yarn diameters. The green ground weave shows a weft-faced tabby. The decoration of the purple-coloured medallions (orbiculi) and the stripes (clavi, but once manicae, cuff bands) is made in tapestry technique, which was woven into the ground fabric. For the elaborate geometric pattern flying thread and soumak were used while the textile was on the loom. All preserved selvedges and borders are decorated with multi-coloured fringes. In its current state, the fragment is badly damaged and shows traces of repairing, mending and reworking. It can, however, be reconstructed as a colourful wool tunic with rich decorations (fig. 4). In comparison with similar artefacts that have been radiocarbon dated, the textile presumably dates from the period after the Arab conquest of Egypt (AD 640/641).

Five samples were selected for dyestuff analysis to determine all colours of the textile: red, green, yellow of the ground weave; purple and light purple of the clavi. The analysis was performed with ultra-high performance liquid chromatography coupled with photodiode array detection (UHPLC-PDA) by Maarten R. van Bommel in cooperation with the University of Amsterdam and the Rijksdienst voor het Cultureel Erfgoed. The results refer to the use of woad or indigo, madder types and weld (Table 1).

Due to its large size, it is not possible to display the original textile fragment in the Papyrussammlung, however, a modern reproduction is planned. In order to replicate the colours, we considered not only the results of the UHPLC-PDA analysis but also the colours preserved on the textile. Furthermore, we examined the evidence from papyrus texts, especially the information that ancient dyers were able to reproduce a desired colour hue according to a small sample.

42. Bogensperger 2014 with comprehensive technical details.
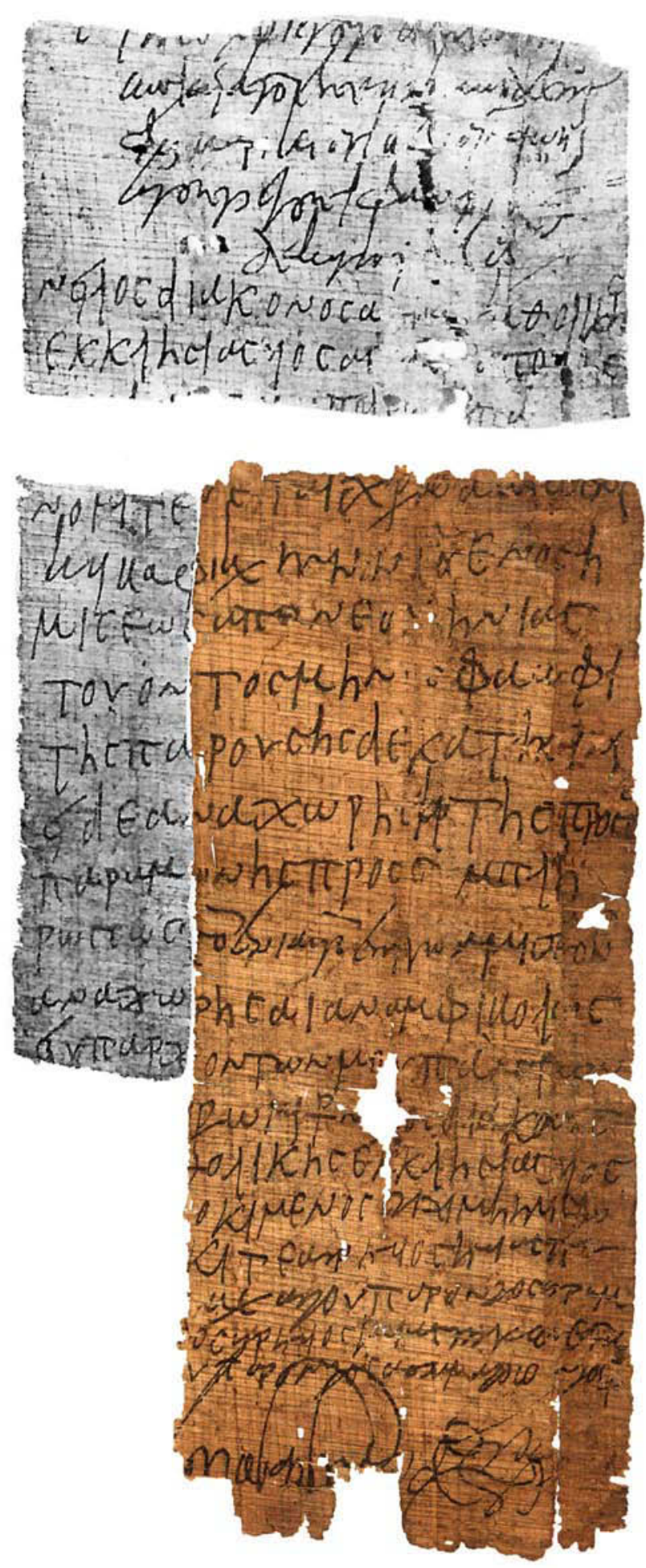

Figure 3. Graphic reconstruction of $C P R$ XIX 33: two fragments held in Paris (MN 6846 App. $708+$ MN 6846 App. 325), one in Vienna (P. Vindob. G 25648). Reconstruction from photos published in CPR XIX. (Reconstruction (C) Ines Bogensperger). 


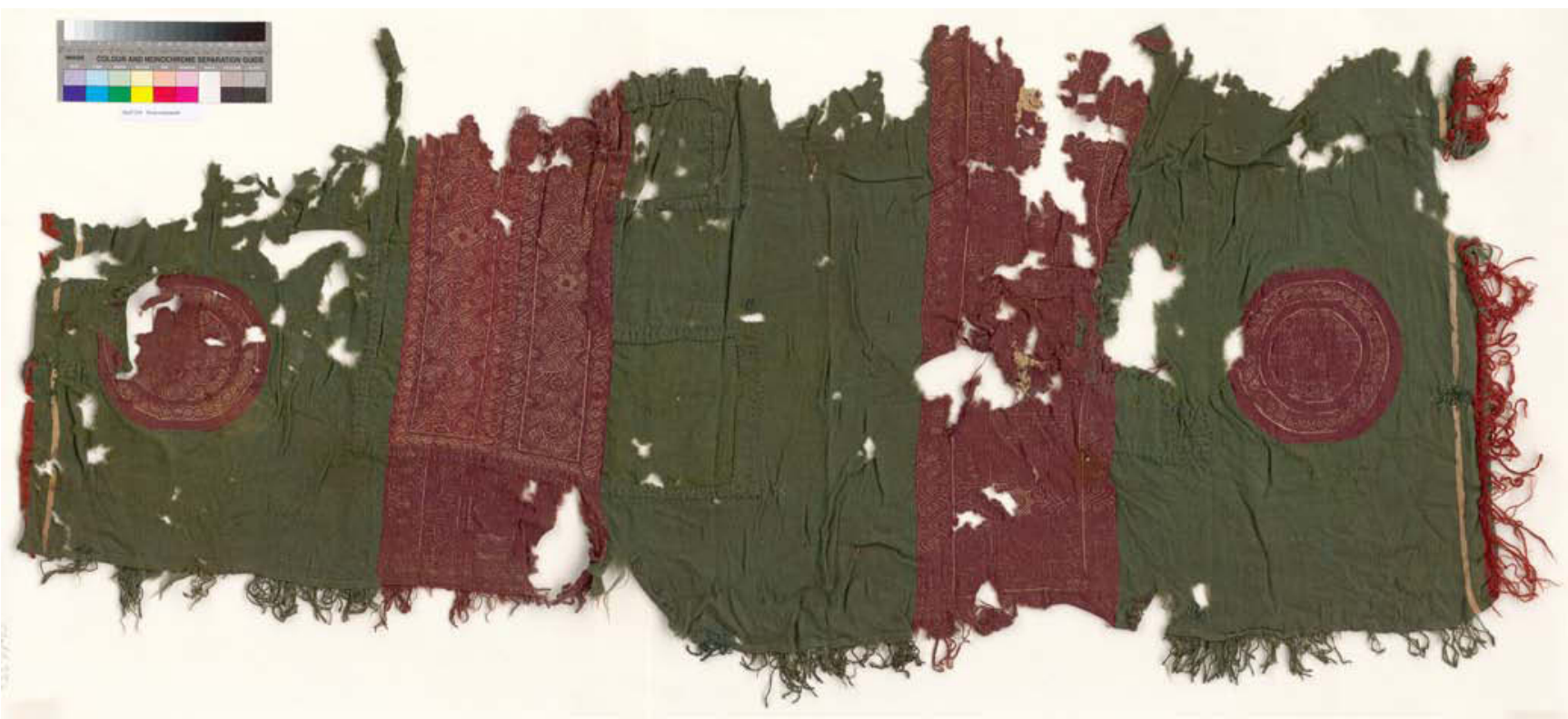

Figure 4. Textile fragment: P. Vindob. Stoff 256, Papyrussammlung, Austrian National Library. (Photo (C) Austrian National Library, Vienna).

Table 1: Summary of the results and the interpretation of the UHPLC-PDA analysis of P. Vindob. Stoff 256.43

\begin{tabular}{|c|c|c|c|}
\hline Colour & Sample location & Dyeing components & Dyeing material \\
\hline \multirow[t]{2}{*}{ Green } & \multirow{2}{*}{$\begin{array}{l}\text { ground fabric } \\
\text { between orbiculus } \\
\text { and clavus }\end{array}$} & indigotin, indirubin, isatin & $\begin{array}{l}\text { woad (Isatis tinctoria L.) or } \\
\text { indigo (Indigofera tinctoria L.) }\end{array}$ \\
\hline & & luteolin, apigenin & weld (Reseda luteola L.) \\
\hline \multirow[t]{2}{*}{ Purple } & \multirow[t]{2}{*}{$\begin{array}{l}\text { area of the hem of } \\
\text { the clavus }\end{array}$} & indigotin, indirubin, isatin & $\begin{array}{l}\text { woad (Isatis tinctoria L.) or } \\
\text { indigo (Indigofera tinctoria L.) }\end{array}$ \\
\hline & & $\begin{array}{l}\text { alizarin, purpurin, } \\
\text { rubiadin, xanthopurpurin }\end{array}$ & $\begin{array}{l}\text { madder types (Rubia tinctorum L. } \\
\text { or Rubiaceae species) }\end{array}$ \\
\hline \multirow[t]{2}{*}{$\begin{array}{l}\text { light } \\
\text { purple }\end{array}$} & \multirow{2}{*}{$\begin{array}{l}\text { bright purple- } \\
\text { coloured sleeve } \\
\text { band }\end{array}$} & $\begin{array}{l}\text { alizarin, purpurin, } \\
\text { rubiadin, xanthopurpurin }\end{array}$ & $\begin{array}{l}\text { madder types (Rubia tinctorum L. } \\
\text { or Rubiaceae species) }\end{array}$ \\
\hline & & indigotin (small amount) & $\begin{array}{l}\text { woad (Isatis tinctoria L.) or } \\
\text { indigo (Indigofera tinctoria L.) }\end{array}$ \\
\hline Red & red fringes & $\begin{array}{l}\text { alizarin, purpurin, } \\
\text { rubiadin, xanthopurpurin }\end{array}$ & $\begin{array}{l}\text { madder types (Rubia tinctorum L. } \\
\text { or Rubiaceae species) }\end{array}$ \\
\hline Beige & repaired clavus & Luteolin & weld (Reseda luteola L.) \\
\hline
\end{tabular}

Dyeing with madder: the reproduction of the red colour of the fringes

The first case study concerns the red colour of the fringes (fig. 5). In the analysis, alizarin, purpurin, rubiadin and xanthopurpurin were detected which point to the use of madder types (Rubiaceae species). According to Jan Wouters and his collaborators, as well as Helmut Schweppe, species of Rubiaceae differ in composition as well as in dye yield. ${ }^{44}$ Rubia tinctorum L. contains more alizerin than purpurin compared to Rubia peregrina L., which has more purpurin than alizerin. A ratio of at least $75 \%$ alizerin and $25 \%$ purpurin is presumably indicative of dyer's madder (Rubia tinctorum L.). Other ratios might 


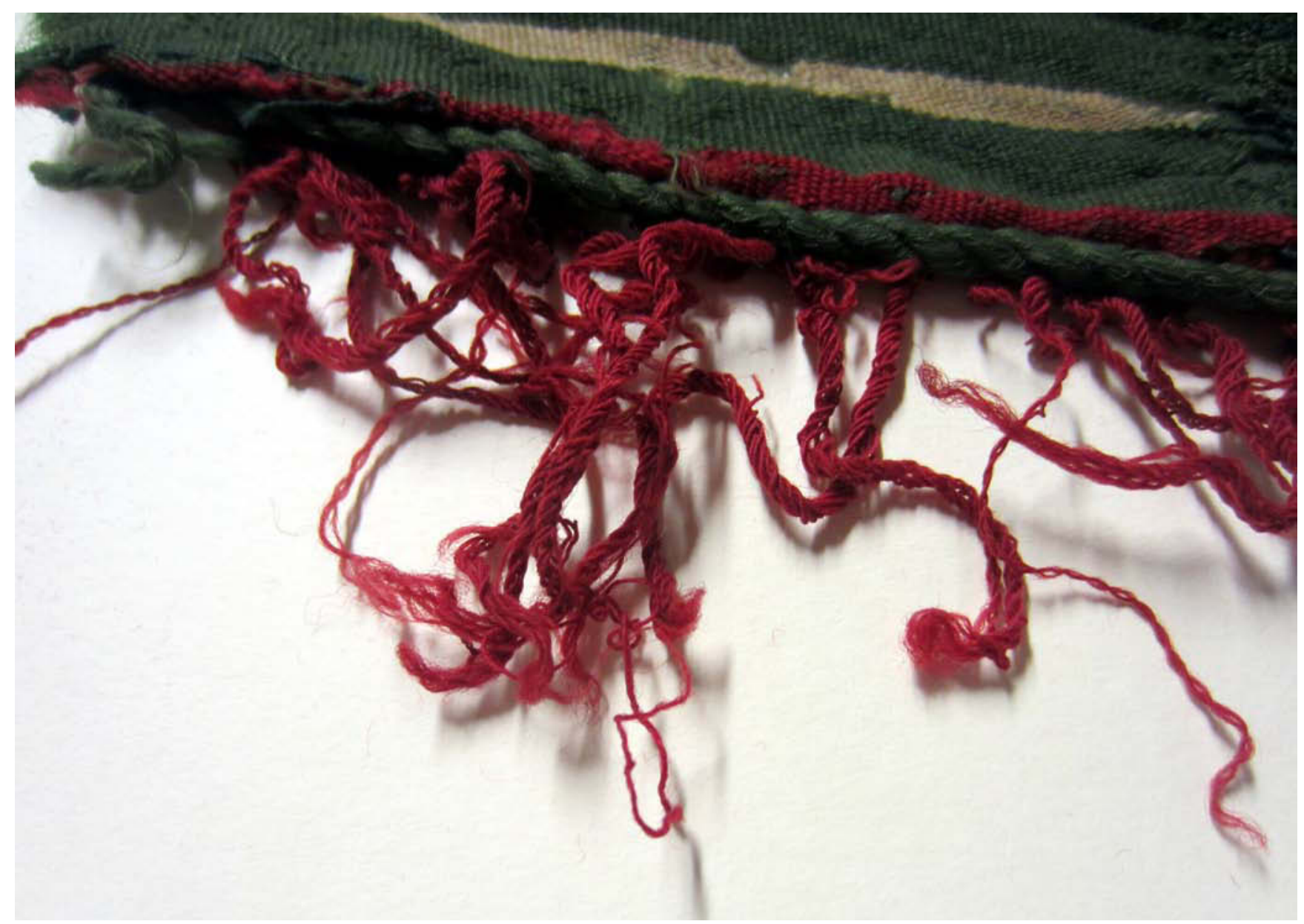

Figure 5. Red dyed fringes of $P$. Vindob. Stoff 256. (Photo: Ines Bogensperger (C) Austrian National Library, Vienna).

point to the use of other Rubiaceae species (or even mixtures of them), such as Rubia peregrina L. or Galium species. It might result from a special dyeing procedure, such as top dyeing of madder red with a woad or indigo vat, or a special treatment of dyer's madder after harvesting and before dying. Amongst the analysed late antique textiles, the ratio between alizarin and purpurin usually differs from "modern" madder: for example, the result of $P$. Vindob. Stoff 256 shows a higher content of purpurin.

In ancient dyeing recipes, madder is rarely attested. Out of the 83 recipes in P. Holm. and P. Leid. X, madder is only mentioned in four. ${ }^{45}$ The first text refers to how to verify the madder quality (P. Holm. 125), the second has a list of various plants and insects for dyeing red ( $P$. Holm. 133), and the remaining two are similar recipes about overdyeing of light blue wool with red (P. Holm. 112; P. Holm. 159).

All results of other textiles of the Papyrussammlung analysed in the course of the research project differ from the written evidence: out of 36 samples of red shades, 31 samples contain madder types; 11 samples contain additional dyestuffs to achieve orange or purple, or use other red dyestuffs like cochineal or alkanet.

Due to the lack of an ancient recipe where madder was used as the only main dyestuff, we had to turn to a modern recipe. As our first step, wool was prepared with alum and tartar, and dyed at $70^{\circ} \mathrm{C}$ (Table 2, nos. 1-6). Considering a previous dyeing experiment based on a passage in Pliny's Natural History (Plin. Nat. 35.42), we applied a liquid containing alum, vinegar and water with a brush on specific parts of a woollen fabric without a separate mordant bath. ${ }^{46}$ Alum clearly modified the brightness of the colour, however, we could not observe any effect caused by tartar. Thus, we reduced the alum to $15 \%$.

In the course of our practical experiments, we changed the amount of madder to $150 \%$ to achieve a more intense colour (fig. 6). The following experiments were dyed in a 


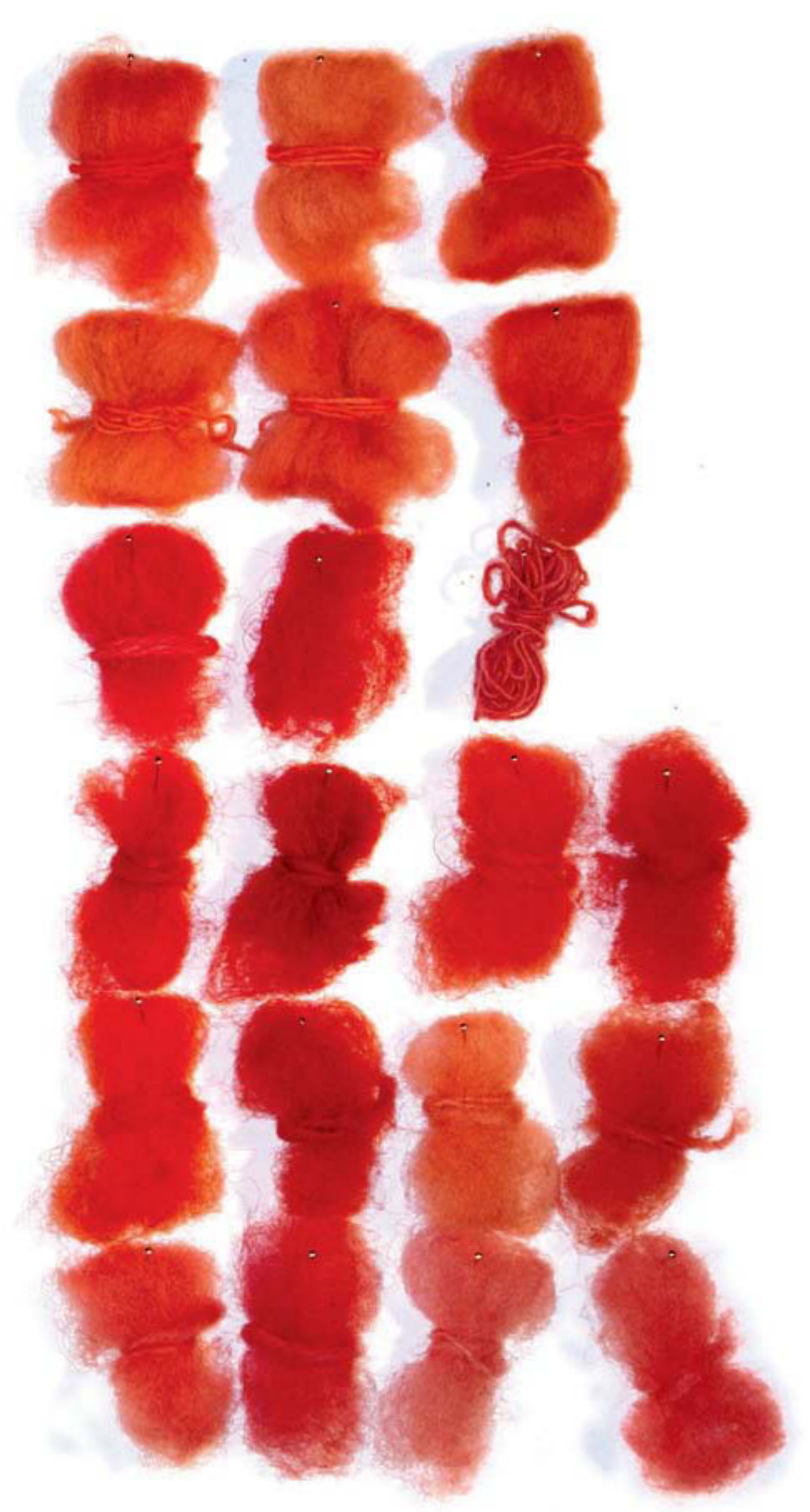

Figure 6. Colour spectrum of madder dyed wool. (Photo (C) Helga Rösel-Mautendorfer).

cold dye bath at $22^{\circ} \mathrm{C}$ for 24 hours, with the exception of no. 8, which was additionally boiled for one minute after the cold dye bath. As a reference, we added wool that had not been in a mordant bath before (Table 2, nos. 7-9). The cold-dyed samples were redder than the samples of the hot dye. The best match was no. 8, where a cold dye was combined with boiling only over a short time. The sample without mordant was duller and the colour appeared more violet (no. 9).

\section{Experiments with previously treated madder}

For nos. 10 to 21, we used pre-treated madder. A first batch of madder roots was slowly dried at an average of $19^{\circ} \mathrm{C}$. A second batch was desiccated at $100^{\circ} \mathrm{C}$ for 90 minutes and afterwards at $50^{\circ} \mathrm{C}$ for 90 minutes. A third batch with fresh roots was steamed in a sieve over boiling water for 180 minutes in a covered pot. Due to the drying process, the weight was generally reduced to approximately $75 \%$. The colour of the roots differed after the drying process.

For the dye bath, we used prepared wool (14\% alum) and $150 \%$ roughly ground madder per sample. We chose four different procedures: a cold dye bath at $22^{\circ} \mathrm{C}$ for 24 hours; a cold dye bath at $22^{\circ} \mathrm{C}$ for 24 hours with an additional boiling at $100^{\circ} \mathrm{C}$ for 1 minute; a hot dye bath at $70^{\circ} \mathrm{C}$ for 2 hours; and a hot dye bath at $70^{\circ} \mathrm{C}$ for 2 hours which was additionally boiled for 1 minute at $100^{\circ} \mathrm{C}$ (Table 2, nos. 10-21).

The results yielded a great variety of reds (fig. 6). Boiling for a short time after the cold or hot dye bath resulted in a darker shade. The cold dyed samples were paler than the hot dyed ones. A paler colour was obtained with the steamed roots. To get more intense hues, it is necessary to use a higher percentage of the dyestuff (about 200\%). Overall, the colour seemed less yellowish than the first batch. The hot dyed wool of the air-dried roots showed the most intense colour. This, however, might be due to the constant temperature of the dye bath at $65^{\circ} \mathrm{C}$.

The dyed samples were to be analysed by UHPLC in order to evaluate any effects of the ratio between alizarin and purpurin 47 .

\section{Double-dyeing with madder and plants containing indigotin: the reproduction of the purple colour of the clavi and the orbiculi}

The second case study examined dyeing of the reddish purple used for the ornaments of the tunic. According to UHPLC-PDA analysis, the components (indigotin, indirubin and isatin and alizarin, purpurin, rubiadin and xanthopurpurin) indicate a double dyeing of red madder and blue woad, or other Indigofera species, which results in a purple colour.

The sequence of the double dyeing was a crucial subject of discussion and decision for our experiments. Modern dyers use both ways, blue - red and red - blue. ${ }^{48}$ To control the darkness and obscurity of the colour, it is easier in practical terms to dye red in the first step and blue

47. Scheduled for the end of December 2018.

48. Regarding the different techniques of mordant and vat dyeing, see Cardon 2007, p. 4-6; Schweppe 1993 , p. 66o-661. 


\begin{tabular}{|c|c|c|c|c|c|c|c|c|c|c|c|c|c|c|c|c|c|c|c|c|c|}
\hline 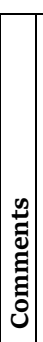 & & 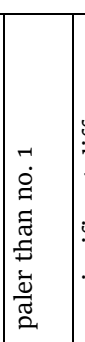 & 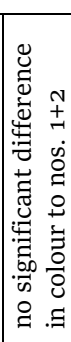 & 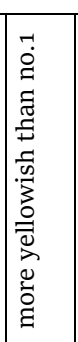 & 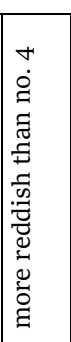 & 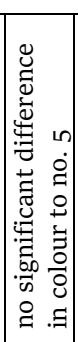 & & 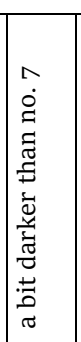 & 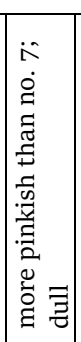 & & 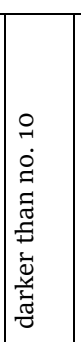 & 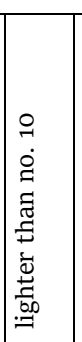 & 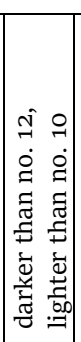 & & 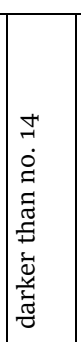 & 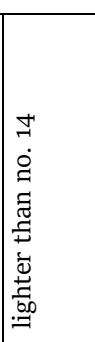 & 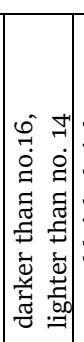 & 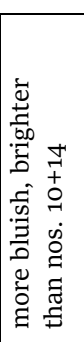 & 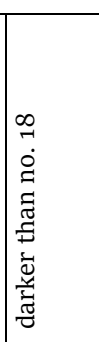 & 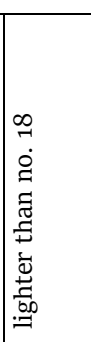 & 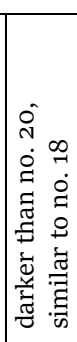 \\
\hline $\begin{array}{l}\vdots \\
\vdots \\
0 \\
0\end{array}$ & 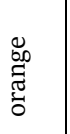 & 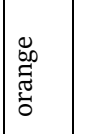 & \begin{tabular}{|l}
$\tilde{\Delta}$ \\
$\infty$ \\
$\tilde{\Xi}$ \\
$\tilde{\sigma}$
\end{tabular} & 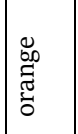 & \begin{tabular}{|l}
0 \\
$\infty$ \\
$\Xi$ \\
$\widetilde{0}$ \\
$\tilde{\sigma}$
\end{tabular} & 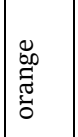 & 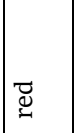 & 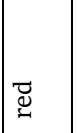 & 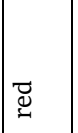 & 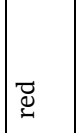 & $\underset{\Xi}{\Xi}$ & $\underset{\varpi}{\varpi}$ & $\underset{\varpi}{\mathscr{D}}$ & 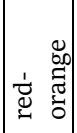 & 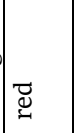 & 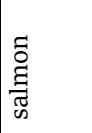 & 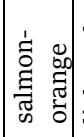 & 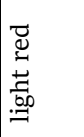 & 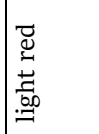 & 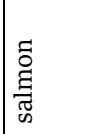 & 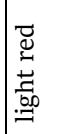 \\
\hline | & $\stackrel{\vec{N}}{\mathrm{~N}}$ & 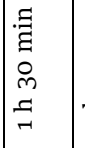 & $\frac{\pi}{\text { N }}$ & 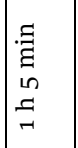 & กี & $\stackrel{\text { N }}{\mathrm{v}}$ & $\frac{4}{4}$ & 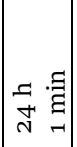 & 先 & $\stackrel{\vec{N}}{\mathrm{~N}}$ & 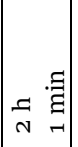 & $\frac{4}{4}$ & 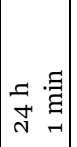 & $\stackrel{\text { ก }}{\leftrightarrows}$ & 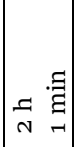 & $\frac{\text { d }}{\pi}$ & 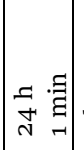 & $\stackrel{\text { ก }}{\pi}$ & 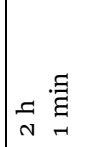 & $\frac{\pi}{\text { N }}$ & 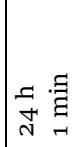 \\
\hline 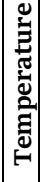 & 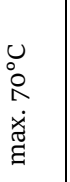 & 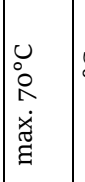 & 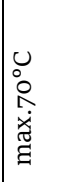 & 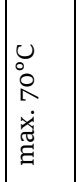 & 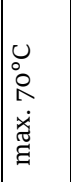 & \begin{tabular}{|l}
0 \\
0 \\
0 \\
$\dot{0}$ \\
$\dot{x}$ \\
$\check{g}$ \\
\end{tabular} & đิ & $\left|\begin{array}{lll}0 & 0 \\
0 & 0 \\
0 & 0 \\
N & 0\end{array}\right|$ & 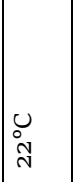 & $\begin{array}{l}0 \\
0 \\
0\end{array}$ & $\mid \begin{array}{lll}0 & 0 \\
0 & 0 \\
1 & 0 \\
1 & 0\end{array}$ & $\mid \begin{array}{l}0 \\
0 \\
\text { N }\end{array}$ & 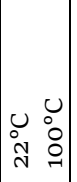 & $\begin{array}{l}0 \\
0 \\
0\end{array}$ & $\begin{array}{|cc|}0 & 0 \\
0 & 0 \\
0 & 0 \\
1 & 0\end{array}$ & $\begin{array}{l}U \\
\text { N } \\
\text { N }\end{array}$ & $\begin{array}{ll} & 0 \\
0 & 0 \\
\text { N } & 0 \\
\text { N } & 0\end{array} \mid$ & $\begin{array}{l}0 \\
0 \\
0 \\
1\end{array}$ & $\mid \begin{array}{ll}0 & 0 \\
0 & 0 \\
0 & 0 \\
1 & 0\end{array}$ & $\begin{array}{l}0 \\
\stackrel{u}{N} \\
\text { N }\end{array}$ & 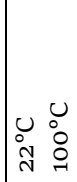 \\
\hline & 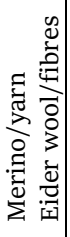 & 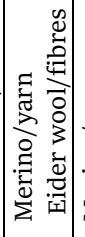 & 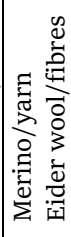 & 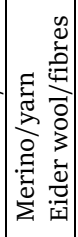 & 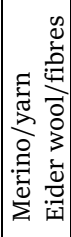 & 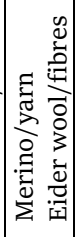 & 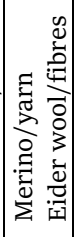 & 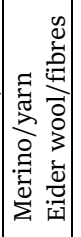 & 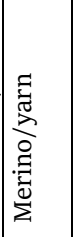 & 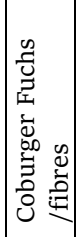 & 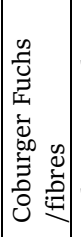 & 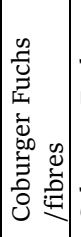 & 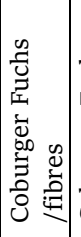 & 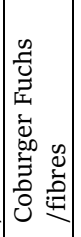 & 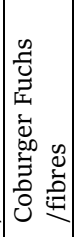 & 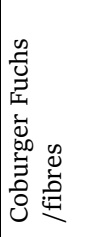 & 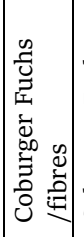 & 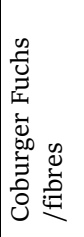 & 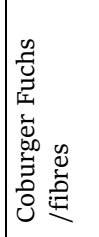 & 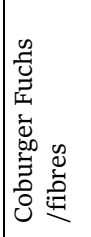 & 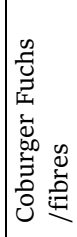 \\
\hline 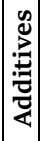 & & 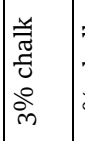 & 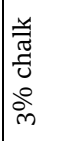 & & 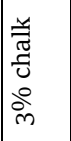 & 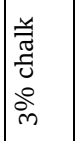 & | & 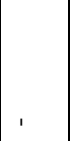 & & & i & ' & ' & , & , & & ' & I & & ' & \\
\hline
\end{tabular}

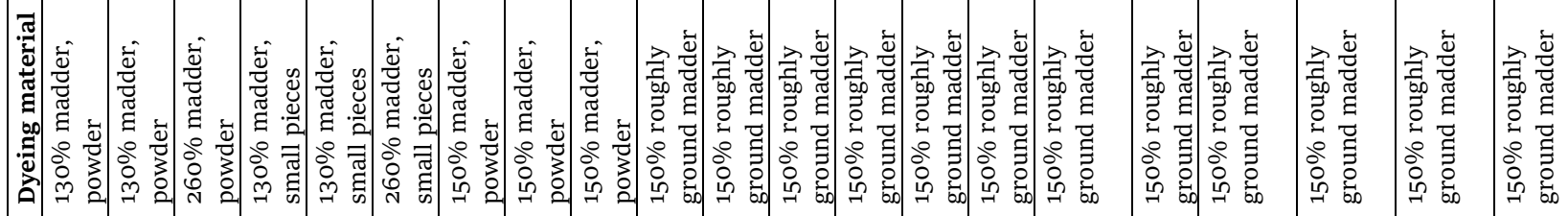

\begin{tabular}{|c|c|c|c|c|c|c|c|c|c|c|c|c|c|c|c|c|c|c|c|c|}
\hline 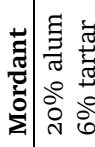 & 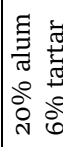 & 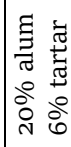 & 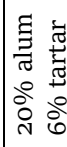 & 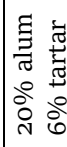 & 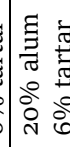 & 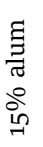 & 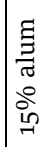 & 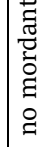 & 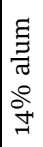 & 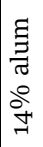 & 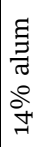 & 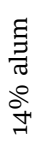 & 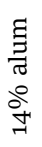 & 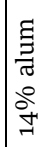 & 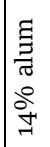 & 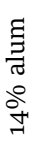 & 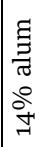 & 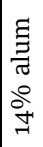 & 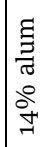 & 毛 \\
\hline$|\dot{\hat{z}}|_{-}$ & N & $\mathrm{m}$ & H & in & 0 & $\Lambda$ & $\infty$ & $a$ & 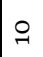 & $F$ & 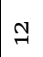 & $m$ & $\exists$ & 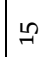 & $\stackrel{\sim}{\circ}$ & $\hat{A}$ & $\stackrel{\infty}{\sim}$ & $F^{\prime}$ & ì & $\mathrm{N}$ \\
\hline
\end{tabular}




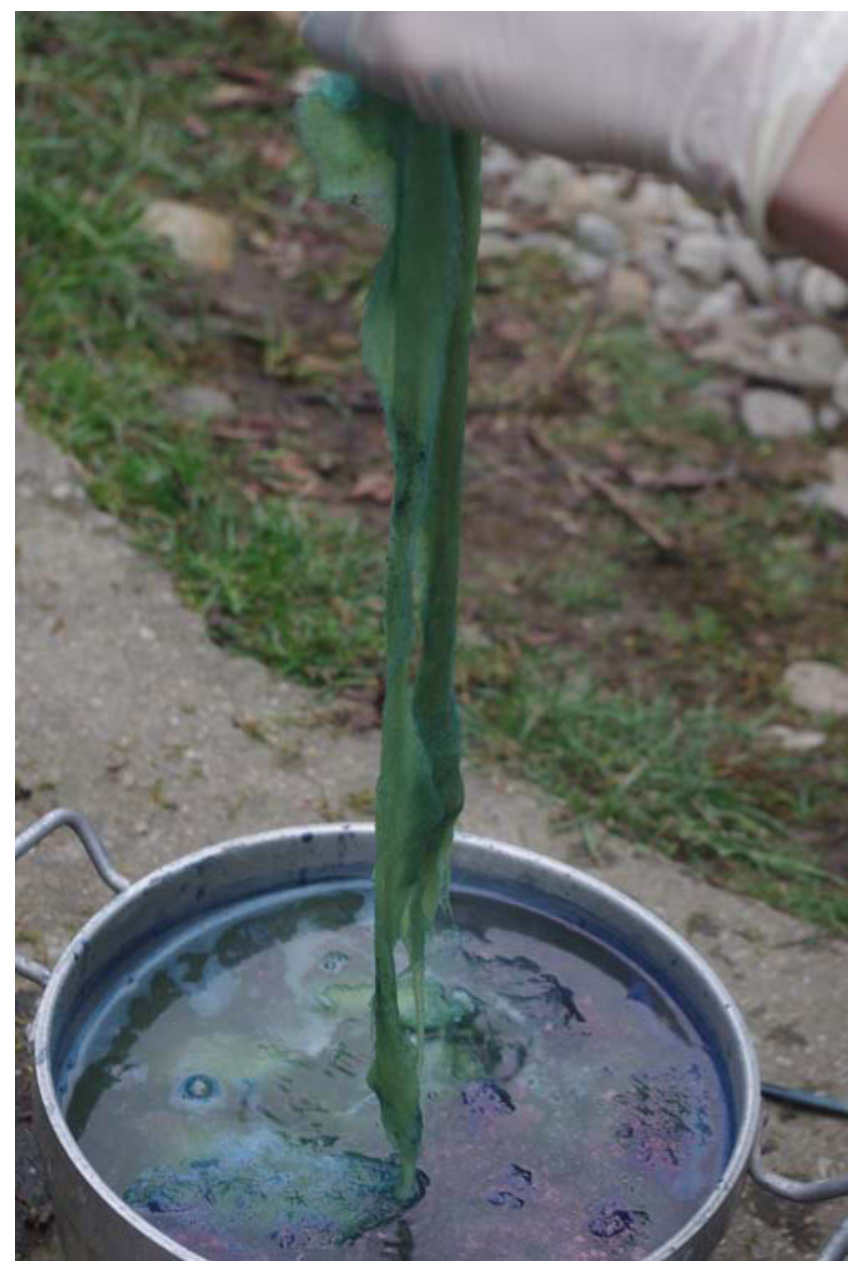

Figure 7. Vat dyeing. (Photo (C) Georg Rösel).

in the second. In the vat, the wool is dyed in subsequent "dippings" until the desired purple hue is obtained (fig. 7). In the reverse order, it is more difficult to estimate a suitable blue for the first dyeing, in particular for an inexperienced dyer. This sequence runs the risk of obtaining too dark a blue.

However, in the ancient recipes, dyeing blue is mentioned first followed by a red overdyeing (e.g., P. Holm. 111). For our experiments with purple, we started with a vat dye according to the sequence of the ancient recipes. We used an indigo-hydrosulphide vat, which gives a relatively quick result and works well with wool. Four different shades resulted from one dipping, two dippings, three dippings, and the last sample with one dipping in the depleted vat. In the second mordant dyeing, the dried madder roots were used with $15 \%$ alum. The dye bath was kept at $22^{\circ} \mathrm{C}$ for 24 hours with $150 \%$ madder. The experiments with one, two and three dippings gave a very dark purple shade compared with the original textile $P$. Vindob. Stoff.
The light blue sample of the depleted vat, however, resulted in a reddish shade of purple, which in fact matches well with the original colour. It is noteworthy that the use of a light blue dyed wool is literally attested in the ancient rec-

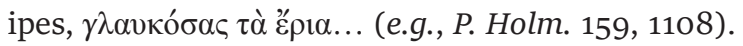

\section{Double dyeing with weld and indigoid plants: the reproduction of the green colour of the main fabric}

The third case study concerned how to obtain the green colour of the ground weave of $P$. Vindob. Stoff 256. Following our previous discussions on double dyeing, we started with blue. Three samples were dyed in an indigo-hydrosulphide vat with one, two and three dippings. After the mordant bath with $15 \%$ alum, we dyed the samples with $200 \%$ weld at $90^{\circ} \mathrm{C}$ for 1 hour. As a reference, we used a wool sample pre-mordanted with alum in order to estimate the intensity of the yellow colour.

The green colour of the samples from one and two dippings matched reasonably well. However, for the reproduction of the original tunic, a large piece of fabric $155 \times 350$ $\mathrm{cm}$ was needed. Therefore, we cooperated with Joseph Koó, a professional indigo dyer. In order to estimate the intensity of the blue vat dye and thus the final green, we agreed to reverse the sequence, in other words, to dye yellow first. After mordanting ( $14 \%$ alum), the fabric was dyed together with woollen yarn with $155 \%$ weld for 2 hours at $80^{\circ} \mathrm{C}$. The result was a rather uneven yellow colour due to the fact that the fabric was difficult to move in the dye bath. Interestingly, additionally added woollen yarn showed a different shade than the woven fabric (fig. 8). Thus, different kinds of wool, the quality and processing of the material apparently have an impact on the dyeing result.

We aimed to conduct this third experiment as close as possible under the conditions and circumstances of ancient times. Due to the large piece of fabric, we gained several essential insights into the actual dyeing process, the handling and the duration. The dye bath was first heated to $48^{\circ} \mathrm{C}$. It took another hour to achieve $80^{\circ} \mathrm{C}$, which was the maximum temperature because the large surface of the vessel, measuring $50 \mathrm{~cm}$ in diameter, led to a considerable temperature loss. Heating large amounts of water takes a relatively long time and is very resource intensive. It seems plausible that in ancient times, lower temperatures were used for dyeing, which would require more time to achieve an intense colour.

Our vessel turned out to be too small for the large textile, as it could not be stirred easily. One has to assume relatively large vessels were used in ancient times, in particular for dyeing woven fabrics. Nevertheless, to achieve boiling temperature for a large volume is challenging. In P. Holm. 110, 779, a vessel for a vat dye containing 15 


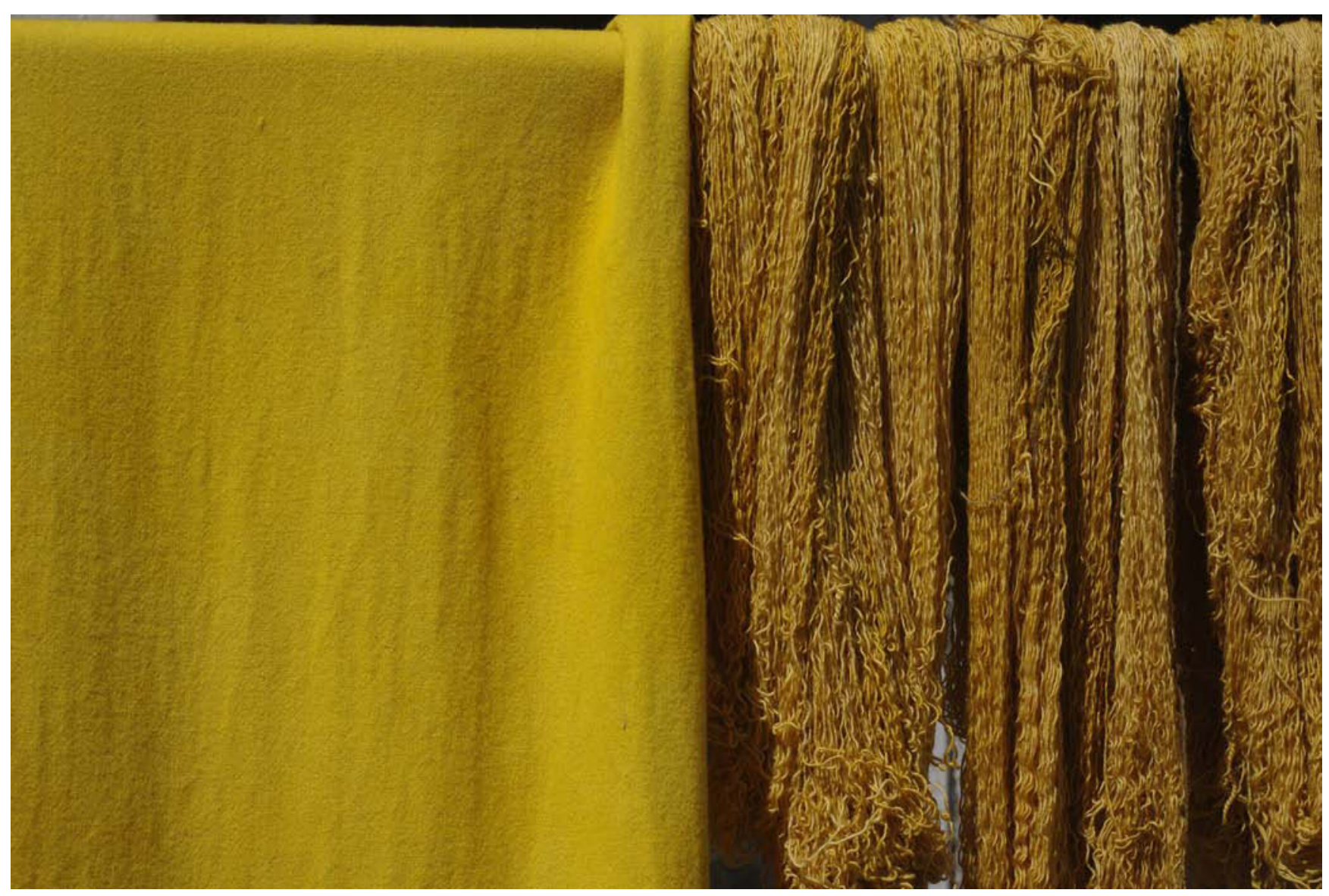

Figure 8. Large fabric and yarns dyed in the same dye bath. (Photo (C) Helga Rösel-Mautendorfer).

$\mu \varepsilon \tau \rho \eta \tau \alpha$ is attested, which converts to c. 550 litres. ${ }^{49}$ In comparison, a dyeing basin in J. Koó's modern workshop has a diameter of $1 \mathrm{~m}$ to a depth of approximately $4 \mathrm{~m}$ and can contain roughly 3000 litres (fig. 9).

For overdyeing with blue, we worked in J. Koó's workshop. His own vitriol vat mainly consists of water, indigo and lime. The dyeing was carried out as a cold dyeing. In order to achieve the exact colour of the original textile, the fabric was repeatedly dipped into the vat for 2 minutes each time. Between dippings, the fabric was dried in the air for 10 minutes to ensure a sufficient oxidation process. After dyeing, the fabric was rinsed out with cold water and dried in the open air. Our final results matched well with the original green colour (fig. 10).

\section{Conclusion}

The ancient texts reflect the importance and professionalism of dyeing craftsmanship. They highlight the logistics through reference to colour samples and they demonstrate the complexity of dyeing.

Dyeing experiments offer a good insight into the dyeing techniques and reveal some parameters which influence the colours. On the subject of madder, it was shown that even a slight change in the recipe results in a different hue. In the case of yellow, it has become significant how the type and the quality of the wool can influence the colour. Therefore, ancient dyers had to react according to the material in order to achieve the desired shade and to fulfil their customers' expectations. Experience and practical knowledge are crucial in estimating the correct colour, especially when wet, since different materials behave differently during the drying process.

When considering large quantities of fabric or fleece, certain conditions must be met. The size of the vessel is decisive for an evenly dyed result. Larger textiles were probably dyed in less hot dye baths, as a larger water surface leads to a considerable temperature loss.

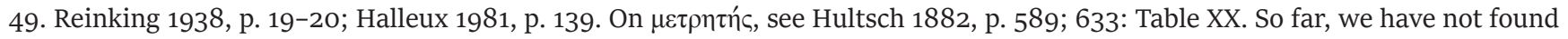
any exact measurements for dyeing pots from archaeological sites. 


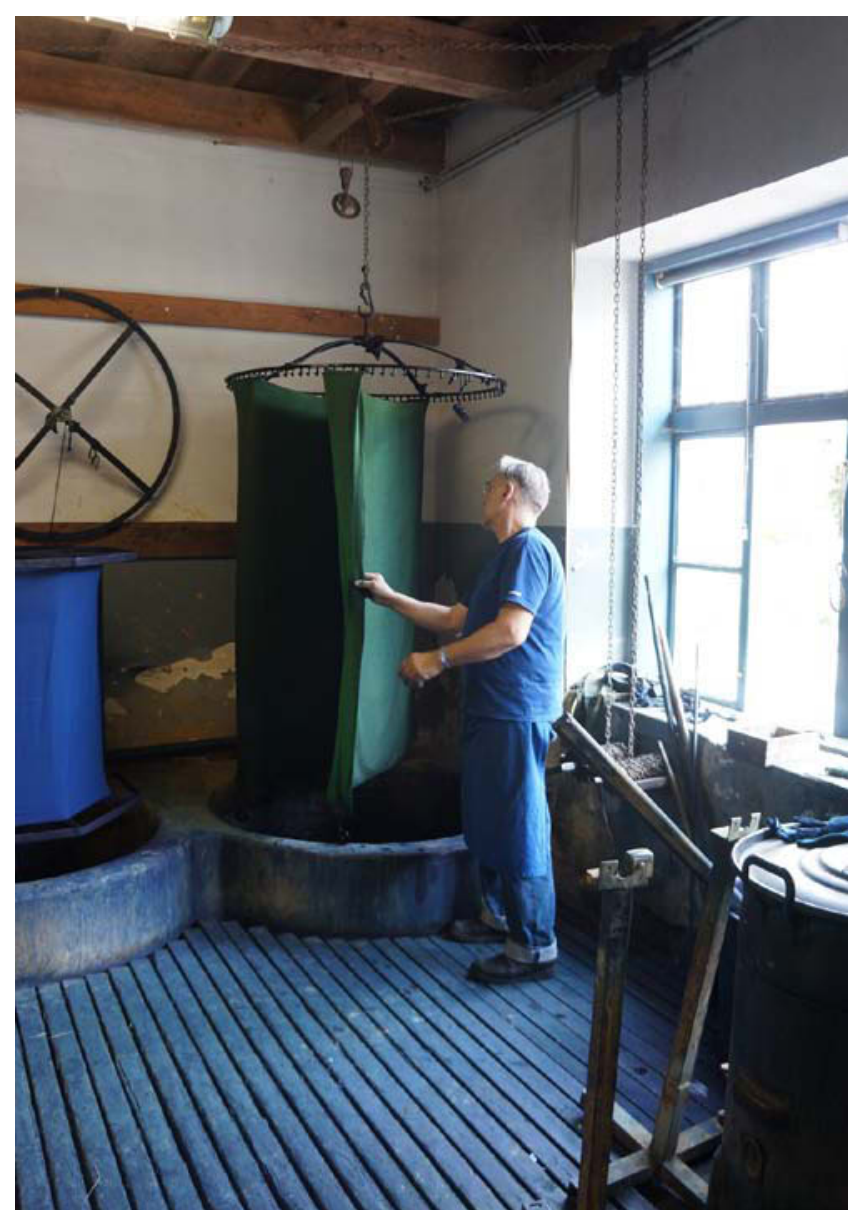

Figure 9. Vat dyeing in the professional dyeing workshop 'Blaudruckerei Koó'. (Photo (c) Ines Bogensperger).

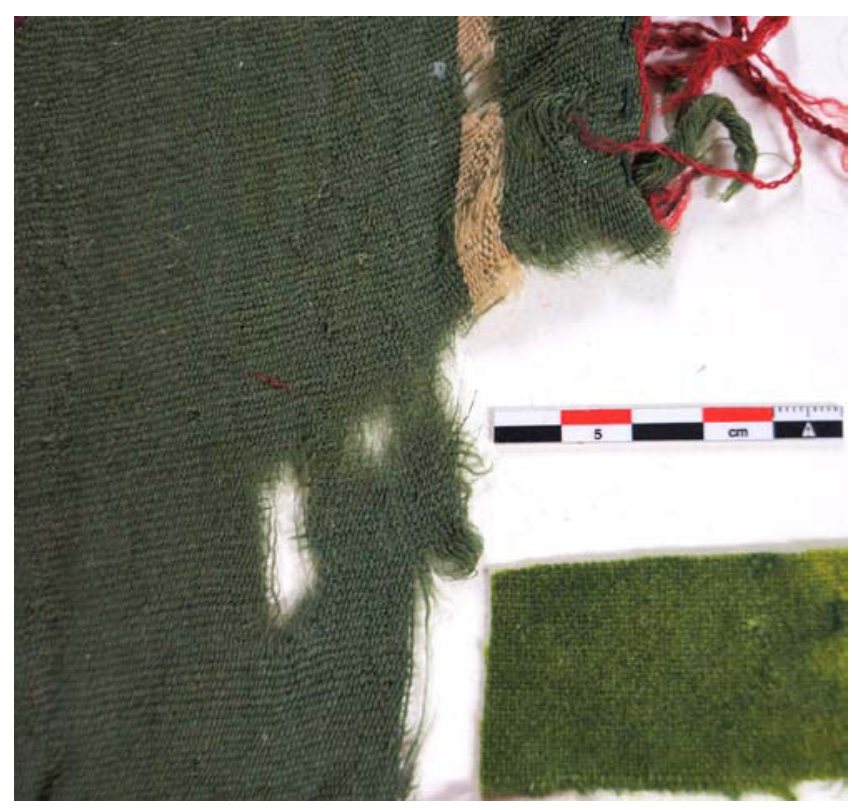

Figure 10. Comparison of $P$. Vindob. Stoff 256 with, bottom right, a small sample of double-dyed fabric. (Photo (C) Ines Bogensperger).
Our experiments in the double dyeing of blue and red for purple confirmed the sequence of "blueing wool", which we have found in the ancient recipes. In practical terms, it was of course possible to change this sequence.

Texts, textiles and experiments reflect the complexity of ancient dyeing technology. Besides practical knowledge and experience, a certain amount of creativity and spontaneity was required to react to unforeseen circumstances caused by the material, the ordered colour, or the colour intensity of the dye. Attention had to be paid to the underlying logistics, since the materials required for dyeing had to be available from other sectors, such as agriculture, animal husbandry and mining. The often only seasonally obtainable materials presumably influenced the high value of dyed textiles because dyeing materials that have been stored too long loose their colour intensity. The reproduction of a particular colour is certainly a demanding challenge and may have required some kind of dyeing tests even in ancient times. The complex process, the modus operandi of the ancient dyeing industry, might have involved the exchange and the use of colour samples in order to provide an idea of the exact colour.

\section{Abbreviations}

- All abbreviations of Latin authors follow the index of the Thesaurus Linguae Latinae. Ancient Greek authors follow the abbreviations of the Oxford Classical Dictionary.

- All papyrological works and all references to papyri, ostraca, etc. follow J.F. Oates, R.S. Bagnall, S.J. Clackson, A.A. O'Brien, J.D. Sosin, T.G. Wilfong \& K.A. Worp (eds.), Checklist of Greek, Latin, Demotic and Coptic Papyri, Ostraca and Tablets. Available at: https:// library.duke.edu/rubenstein/scriptorium/papyrus/ texts/clist_papyri.html (continually updated)

- The numbers of the dyeing recipes as well as the line numbers follow the edition of Halleux 1981.

\section{Bibliography}

Andersson Strand, E. (2012) “The Textile chaîne opératoire: Using a Multidisciplinary Approach to Textile Archaeology with a Focus on the Ancient Near East", Paleorient 38, p. 1-2.

Andorlini, I. (1998) "I colori dei tessuti", in L. Del Francia Barocas (dir.), Antinoe cent'anni dopo. Catalogo della mostra Firenze Palazzo Medici Riccardi, 10 luglio1 novembre 1998, Florence, p. 154-16o.

Bagnall, R.S. (2008) "SB 6.9025, Cotton and the Economy of the Small Oasis", Bulletin of the American Society of Papyrologists 45, p. 21-30. 
Beekes, R.S.P. (2010) The Etymological Dictionary of Greek. With the assistance of Lucien van Beek. Indo-European Etymological Dictionary Series 10, Leiden.

Berthelot, M. (1887) Collection des anciens alchimistes grecs. Vol. I, Paris.

Bogensperger, I. (2014) "The Multiple Functions and Lives of a Textile: The Reuse of a Garment”, in M. Harlow \& M.-L. Nosch (eds.), Greek and Roman Textiles and Dress. An Interdisciplinary Anthology. Ancient Textiles Series 19, Oxford, p. 335-344.

Bogensperger, I. (2016) "How to Order a Textile in Ancient Times? The Step before Distribution and Trade", in K. Droß-Krüpe \& M.-L. Nosch (eds.), Textiles, Trade and Theories. From the Ancient Near East to the Mediterranean. Kārum - Emporion - Forum 2, Münster, p. 259-270.

Bogensperger, I. (2017) "Purple and its Various Kinds in Documentary Papyri”, in S. Gaspa, C. Michel \& M.-L. Nosch (eds.), Textile Terminologies from the Orient to the Mediterranean and Europe $1000 B C-A D 1000$. Zea Books 56, Lincoln, p. 235-249. Available at: https:// digitalcommons.unl.edu/texterm/19/

Cardon, D. (2007) Natural Dyes. Sources, Tradition, Technology and Science. London.

Clarke, M. (2013) “The Earliest Technical Recipes: Assyrian Recipes, Greek Chemical Treatises and the Mappae Clavicula Text Family", in R. Córdoba (ed.), Craft Treatises and Handbooks. The Dissemination of Technical Knowledge in the Middle Ages. De diversis artibus 91, Turnhout, p. 9-31.

Flemestad, P. (2020) "Ancient Greek Dyeing: A Terminological approach”, in M. Mossakowska-Gaubert (ed.), Egyptian Textiles and their Production: 'Word' and 'Object' (Hellenistic, Roman and Byzantine Periods). Zea Books 2020, Lincoln, p. 82-90. Available at: http:// digitalcommons.unl.edu/etpwo

Flohr, M. (2013) “The Textile Economy of Pompeii”, Journal of Roman Archaeology 26, p. 53-78.

Froschauer, H. (2007) "Farben und Farbbezeichnungen in Papyri und Textilien“, in N. Bosson \& A. Boud'hors (eds.), Actes du Huitième Congrès International d'Études Coptes. Paris, 28 juin-3 juillet 2004. Orientalia Lovaniensia Analecta 163, Leuven, p. 697-709.

Germer, R. (1992) Die Textilfärberei und die Verwendung gefärbter Textilien im Alten Ägypten. Ägyptologische Abhandlungen 53, Wiesbaden.

Goyon, J.-C. (1996) "Le lin et sa teinture en Égypte. Des procédés ancestraux aux pratiques importées (VIIe siècle av. J.-C. à l'époque récente)", in Aspects de l'artisanat du textile dans le Monde Méditerranéen (Égypte, Grèce, monde Romain). Collection de l'Institut d'Archéologie et d'Histoire de l'Antiquité, Université Lumière Lyon 2, vol. 2, Lyon, p. 13-22.

Guilland, G. (1949) "Sur quelques termes du Livre des Cérémonies de Constantin VII Porphyrogénète”, Revue des Études Grecques 62, p. 333-338.
Halleux, R. (1981) Papyrus de Leyde, Papyrus de Stockholm, Fragments de Recettes. Texte établi et traduit. Les alchimistes grecs I. Paris.

Hartl, A., Néss Proaño Gaibor, A., van Bommel, M.R. \& Hofmann-de Keijzer, R. (2015a) "Searching for Blue: Experiments with Woad Fermentation Vats and an Explanation of the Colours through Dye Analysis", Journal of Archaeological Science: Reports 2, p. 9-39.

Hartl, A., van Bommel, M. R., Joosten, I., Hofmann-de Keijzer, R., Grömer, K., Rösel-Mautendorfer, H. \& Reschreiter, H. (2015b) "Reproducing Colourful Woven Bands from the Iron Age Salt Mine of Hallstatt in Austria: An Interdisciplinary Approach to Acquire Knowledge of Prehistoric Dyeing Technology", Journal of Archaeological Science: Reports 2, p. 569-595.

Hofenk de Graaff, J.H. \& Roelofs, W.G.T. (2004) The Colourful Past: Origins, Chemistry and Identification of Natural Dyestuffs. With contributions from W.G.Th. Roelofs and M.R. van Bommel, Riggisberg.

Hultsch, F. (1882) Griechische und römische Metrologie (2 ${ }^{\text {nd }}$ edition), Berlin.

Kirby, J., Bommel van, M.R., Verhecken, A., Spring, M., Vanden Berghe, I., Stege, H. \& Richter, M. (2014) Natural Colorants for Dyeing and Lake Pigments: Practical Recipes and their Historical Sources, London.

Koroli, A. (2020) "Textile Production in the Papyri: The Case of Private Request Letters", in M. Mossakowska-Gaubert (ed.), Egyptian Textiles and their Production: 'Word' and 'Object' (Hellenistic, Roman and Byzantine Periods).

Zea Books 2020, Lincoln, p. 116-127. Available at: http://digitalcommons.unl.edu/etpwo

Kovarik, S. (2012) "Griechische Texte zu Herstellung und Gebrauch von Textilien”, in B. Palme \& A. Zdiarsky (eds.), Gewebte Geschichte. Stoffe und Papyri aus dem spätantiken Ägypten. Nilus 19, Vienna, p. 109-125.

Kreuzner, C. (2013) "Alkanna Tinctoria (L.) Tausch as Purple Dye in the Recipes of Papyrus Holmiensis and Papyrus Leidensis X", e-Preservation Science 10, p. 123-130.

Kruse, T. (2007) "P.Heid. Inv. G 5166 und die Organisation des Alaunmonopols im kaiserzeitlichen Ägypten”, in J. Frösen (ed.), Proceedings of the 24th International Congress of Papyrology, Helsinki, 1-7 August 2004. Commentationes Humanarum Litterarum 122, Societas Scientiarum Fennica, Helsinki, p. 523-547.

Lagercrantz, O. (1913) Papyrus Graecus Holmiensis (P. Holm.). Recepte für Silber, Steine und Purpur. Arbeten utgifna med understöd af Vilhelm Ekmans Universitetsfond 13, Uppsala - Leipzig.

Leemans, C. (1885) Papyri Graeci Musei Antiquarii Publici Lugduni-Batavi, Leiden.

Lowe, B. (2016) “The Dye Shops of Pompeii”, in J. Ortiz, C. Alfaro, L. Turell \& M.J. Martinez (eds.), Purpureae Vestes V. Textiles, Basketry and Dyes in the Ancient Mediterranean World. Proceedings of the $5^{\text {th }}$ International Symposium on Textiles and Dyes in the Ancient 
Mediterranean World (Montserrat, 19-22 March, 2014), Valencia, p. 239-244.

Martelli, M. (2014) "Alchemical Textiles: Colourful Garments, Recipes and Dyeing Techniques in GraecoRoman Egypt”, in M. Harlow \& M.-L. Nosch (eds.), Greek and Roman Textiles and Dress. An Interdisciplinary Anthology. Ancient Textiles Series 19, Oxford, p. 111-129.

Martínez Garcia, M.J. (2016) “Mordientes orgánicos y drogas fijadoras prescriptas en los papiros Graecus Holmiensis y Leiden X”, in J. Ortiz, C. Alfaro, L. Turell \& M.J. Martínez (eds.), Purpureae Vestes V. Textiles, Basketry and Dyes in the Ancient Mediterranean World. Proceedings of the $5^{\text {th }}$ International Symposium on Textiles and Dyes in the Ancient Mediterranean World (Montserrat, 19-22 March, 2014), Valencia, p. 245-256.

Morelli, F. (2017) "I vestiti nuovi del dandy Apollonios. Tessuti di lusso in P.Giss. I 21", Tyche 32, p. 131-137.

Pfister, R. (1937) Nouveaux textiles de Palmyre découverts par le service des Antiquités du haut-commissariat de la République française dans la nécropole de Palmyre (Tour d'Élahbel), Paris.

Rast-Eicher, A. (2016) Fibres. Microscopy of Archaeological Textiles and Furs, Archaeolingua 36, Budapest.

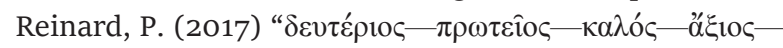
$\psi \imath \lambda o ́ c$. Nochmals zu Beschreibung materieller Wertigkeit in papyrologischen Quellen (Vom Wert der Dinge III)", Marburger Beiträge zur Antiken Handelsgeschichte 35, p. 207-243.

Reinking, K. (1938) Die in den griechischen Handschriften aus dem Altertume erhaltenen Vorschriften für Wollfärberei, Frankfurt.

Reiter, G. (1962) Die griechischen Bezeichnungen der Farben Weiß, Grau und Braun. Eine Bedeutungsuntersuchung, Innsbruck.
Roquero, A. (2006) Tintes y tintoreros de América. Catálogo de materias primas y registro etnográfico de México, Centro América, Andes Centrales y Selva Amazónica, Madrid.

Rösel-Mautendorfer, H. \& Bogensperger, I. (2017) "Plinius der Ältere und das Bemalen von Textilien. Die Rolle der Experimentellen Archäologie zum Verständnis antiker Texte”, in U. Weller, T. Lessig-Weller \& E. Hanning (eds.), Experimentelle Archäologie in Europa. Jahrbuch 2017, Unteruhldingen, p. 70-81.

Ruffing, K. (2008) Die berufliche Spezialisierung in Handel und Handwerk: Untersuchungen zu ihrer Entwicklung und zu ihren Bedingungen in der römischen Kaiserzeit im östlichen Mittelmeerraum auf der Grundlage griechischer Inschriften und Papyri. PHAROS 24, Rahden/Westf.

Schweppe, H. (1993) Handbuch der Naturfarbstoffe. Vorkommen, Verwendung, Nachweise, Hamburg.

Van Bommel, M.R. (2015) HPLC-Report of P. Vindob. Stoff 256 (unpublished), Amsterdam.

Wild, J.P. (1970) Textile Manufacture in the Northern Roman Provinces, Cambridge.

Wipszycka, E. (1965) L'industrie textile dans l'Égypte romaine. Archiwum Filologiczne 9, Wrocław - Warsaw - Cracow.

Worp, W.A. (1997) "On the Meaning of ПОРФҮРА/ ПОРФYРІОN in Greek Documentary Papyri”, Marburger Beiträge zur Antiken Handelsgeschichte 16, p. 57-66.

Wouters, J., Vanden Berghe, I., Richard, G., Breniaux, R. \& Cardon, D. (2008) "Dye Analysis of Selected Textiles from Three Roman Sites in the Eastern Desert of Egypt: A Hypothesis on Dyeing Technology in Roman and Coptic Egypt, Dyes in History and Archaeology 21, p. 1-16. 